\title{
Communication/Comunicação
}

\section{A list of mosquito species of the Brazilian State of Pernambuco, including the first report of Haemagogus janthinomys (Diptera: Culicidae), yellow fever vector and 14 other species (Diptera: Culicidae)}

\author{
Lista de espécies de mosquitos do Estado de Pernambuco e primeiro relato de Haemagogus \\ janthinomys (Diptera: Culicidae) vetor de febre amarela silvestre e outras 14 espécies (Diptera: \\ Culicidae)
}

\section{Nádia Consuelo Aragão1, Gerson Azulim Müller 2,3, Valdir Queiroz Balbino' ${ }^{1}$, César Raimundo Lima Costa Junior' , Carlos Santiago Figueirêdo Júnior ${ }^{1}$,Jerônimo Alencar ${ }^{4}$ and Carlos Brisola Marcondes ${ }^{3}$}

\begin{abstract}
Introduction: Besides mosquito species adapted to urban environments (Culex quinquefasciatus, Aedes aegypti and Aedes albopictus), only 15 species of Anopheles had been recorded in the State of Pernambuco. Methods: Humanlanding mosquitoes were collected in Dois Irmãos Park, in Recife. Results: The first report for the state of Haemagogus janthinomys, an important vector of yellow fever virus, and 14 other species, including Trichoprosopon lampropus, a first reported for Brazil. Conclusions: The mosquito fauna in the area is diversified and has potential medical and veterinary importance.
\end{abstract}

Key-words: Haemagogus janthinomys. New records. Pernambuco.

\section{RESUMO \\ Introdução: Além de mosquitos adaptados ao ambiente urbano (Culex quinquefasciatus, Aedes aegypti e Ae. albopictus), apenas 15 espécies de Anopheles haviam sido relatadas no Estado de Pernambuco. Métodos: Mosquitos que pousavam em humanos no Parque Dois Irmãos, em Recife foram coletados. Resultados: Haemagogus janthinomys, importante vetor de vírus de febre amarela, e outras 14 espécies são relatadas pela primeira vez no estado, incluindo Trichoprosopon lampropus, relatado pela primeira vez no Brasil. Conclusões: A fauna de mosquitos na área é muito diversificada e tem potencial importância médica e veterinária.}

Palavras-chaves: Haemagogus janthinomys. Novos relatos. Pernambuco.

The mosquito fauna of the north-eastern Brazilian state of Pernambuco has been poorly studied. In fact, besides several reports confirming Culex quinquefasciatus, Aedes aegypti and Aedes albopictus, other species from the state have rarely been reported.

Pernambuco is situated in a tropical region, has a diversified climate and vegetation and knowledge of its mosquito fauna is very important. Besides studies concerning mosquitoes related to filariasis

1.Department of Genetics, Federal University of Pernambuco, Recife, PE, Brazil. 2. Graduation in Entomology, Department of Zoology, Federal University of Paraná, Curitiba, PR, Brazil. 3. Department of Microbiology, Immunology and Parasitology, Centre of Biological Sciences, Federal University of Santa Catarina, Florianópolis, SC, Brazil. 4. Laboratory of Diptera, Oswaldo Cruz Institute, Oswaldo Cruz Foundation, Rio de Janeiro, RJ, Brazil.

Address to: Dr. Carlos Brisola Marcondes. Dept ${ }^{\circ}$ Microbiol. Imunol. Parasitol/CCB/ UFSC. Campus Trindade, 88040-900 Florianópolis, SC, Brasil.

Phone: 5548 3721-5208.

e-mail: cbrisola@mbox1.ufsc.br

Received in 08/03/2010

Accepted in 07/04/2010 and dengue, very frequent diseases in several cities, data on other mosquitoes in the state is very scarce. Dirofilariasis was shown to occur in Recife ${ }^{1}$ and malaria transmission has occurred in the past. Although the state is currently outside the distribution of the sylvan cycle of yellow fever ${ }^{2}$, many cities are highly infested by Aedes aegypti, with many cases of dengue.

Collections were developed in a reservation (Dois Irmãos Park), in Recife, State of Pernambuco, Brazil. The park (http:// www.parquedoisirmaos.pe.gov.br/; headquarter: $8^{\circ} 00^{\prime} 32.7^{\prime \prime} \mathrm{S}$ $34^{\circ} 56^{\prime} 42.5^{\prime \prime} \mathrm{W}$, ca. $40 \mathrm{~m}$ a.s.l.) was described previously ${ }^{3}$. Briefly, it includes two lagoons, surrounded by secondary Atlantic forest; it is very humid, mostly in winter, with diversified vegetation, including bromeliads and non-native bamboos. There is a zoo in the reservation and besides visitors to this zoo, many people from the densely populated neighborhood enter the forest.

Plastic suction tubes and collection boxes were used for mosquitoes landing on collectors, from $8 \mathrm{am}$ to $1 \mathrm{pm}$, from July 27 2009 to November 28 2009. Mosquitoes were identified by keys ${ }^{4-6}$, checking original and complementary descriptions of each species. Genera were abbreviated as proposed by Reinert ${ }^{7}$.

The first reports for the State of Pernambuco of the following collected species, with the number of female specimens between parentheses: Coquillettidia hermanoi (17), Cq shannoni (9), Haemagogus janthinomys (5), Limatus durhamii (=Limatus durhami) (8), Mansonia wilsoni (3), Ochlerotatus hastatus/oligopistus/ serratus (1), Oc scapularis (8), Sabethes tarsopus (1), Trichoprosopon lampropus (4), Wyeomyia arthrostigma (1), Wy coenonus/tarsata (1), Wy medioalbipes (5), Wy moerbista/cesari (1), Wy negrensis (1), Wy serratoria (1). This is the firstly report of Tr lampropus for Brazil.

At least 15 species not previously reported in Pernambuco were added to the known mosquito fauna of this state, which included, besides the urban species cited above, 15 of Anopheles: An albitarsis, An argyritarsis, An aquasalis (Plasmodium-infected), An bellator, An braziliensis, An cruzii, An darlingi, An eiseni, Anfluminensis, An intermedius, An lutzi, An parvus, An peryassui, An strodei and An triannulatus.

Haemagogus janthinomys is an important vector of sylvan yellow fever $^{2}$ and Mayaro virus ${ }^{8}$ and more thorough studies should be developed in Recife. Since it is still difficult to differentiate it from $\mathrm{Hg}$ capricornii ${ }^{9}$ and $\mathrm{Hg}$ leucocelaenus was recently reported in $\mathrm{Natal}^{10}$, 
Haemagogus mosquitoes from the north-east region of Brazil need to be carefully studied. Maraú (14006'57'S 38059'37'W) ${ }^{11}$ and Caravelas (17042'48”'S 3959'55"W) ', both in the State of Bahia, are the most northern localities where Hg. janthinomys had previously been reported in Atlantic forest area.

Ochlerotatus scapularis has been incriminated as vector of Dirofilaria immitis in southeastern Brazil ${ }^{12}$. This mosquito has also been artificially infected by Rocio ${ }^{13}$ and yellow fever ${ }^{14}$ viruses and naturally infected by yellow fever virus in an outbreak in the State of Bahia ${ }^{15}$.

Females of mosquitoes of some Wyeomyia species (see above) and of Ocserratus and similar species occasionally still cannot be differentiated. Future collections mostly using light traps, in order to capture males, and examining breeding places, to capture immature forms, need to be developed for a more complete and secure identification.

The presence of $\mathrm{Hg}$ janthinomys and so many species of sylvan mosquitoes in an area where animals of several species (exotic and local) are present and many people circulate may induce the transmission of pathogens.

Ochlerotatus scapularis had been reported from the United States (Texas) to North Argentina, Sa tarsopus from Mexico to Peru and French Guiana, and in Brazil, it had been reported in the States of Amapá, Bahia, Rio de Janeiro and São Paulo. Tr lampropus, is first reported here for Brazil, had previously been reported only from Colombia. Wy negrensis had been reported only from Brazil and Wy arthrostigma, Wy serratoria and Wy medioalbipes from Brazil and other countries.

The high number of new reports of mosquito species for the State of Pernambuco, one of them new for Brazil, emphasizes the need to develop studies in forested areas in this huge country. The finding of a diversified Phlebotomine sandfly fauna exists in this reservation, some of them potential vectors of Leishmania, including several species previously reported only in the Amazon region, reinforces the need of studies on the insect fauna in the area.

\section{ACKNOWLEDGMENTS}

The authors would like to thank the Bundesministerium für Bildung und Forschung (Proc. - 01LB0205) and the Conselho Nacional de Desenvolvimento Científico e Tecnológico (Proc. 690143/01-0) for the financial help to CBM work. GAM receives a PhD scholarship from the CNPq. CSF Jr and CRLC Jr received MSc scholarships from CNPq and FACEPE, respectively.

\section{CONFLICT OF INTEREST}

The authors declare that there is no conflict of interest.

\section{FINANCIAL SUPPORT}

Financial agency: $\mathrm{BMBF}$ and $\mathrm{CNPq}$

\section{REFERENCES}

1. Alves LC, Silva LVA, Faustino MA, McCall JW, Supakonderj P, Labarthe NW, et al. Survey of canine heartworm in the city of Recife, Pernambuco, Brazil Mem Inst Oswaldo Cruz 1999; 94:587-590.

2. Vasconcelos PF. Febre amarela. Rev Soc Bras Med Trop 2003; 36:275-293.

3. Balbino VQ, Coutinho-Abreu IV, Sonoda IV, Marques da Silva W, Marcondes CB. Phlebotomine sandflies (Diptera: Psychodidae) of the Atlantic forest in Recife, Pernambuco state, Brazil: the species coming to human bait, and their seasonal and monthly variations over a 2-year period. Ann Trop Med Parasitol 2005; 99:683-693.

4. Arnell JJ. Mosquito studies (Diptera, Culicidae). XXXII. A revision of the genus Haemagogus. Contributions of the American Entomology Institute 1973; 10:1-174.

5. Consoli RAGB, Oliveira RL. Principais mosquitos de importância sanitária no Brasil. Rio de Janeiro: Editora da Fundação Oswaldo Cruz; 1992.

6. Lane J. Neotropical Culicidae. Tribe Culicini, Deinocerites, Uranotaenia, Mansonia, Orthopodomyia, Aedomyia, Aedes, Psorophora, Haemagogus, tribe Sabethini, Trichoprosopon, Wyeomyia, Phoniomyia, Limatus and Sabethes. Vol. 2. São Paulo: Universidade de São Paulo; 1953.

7. Reinert JF. Mosquito generic and subgeneric abbreviations (Diptera: Culicidae) Mosquito Systematics 1975; 7:105-110.

8. Vasconcelos PFC, Travassos-da-Rosa APA, Pinheiro FP, Shope RE, Travassosda-Rosa JFS, Rodrigues SG, et al. Arboviruses pathogenic for man in Brazil. In: Travassos-da-Rosa APA, Vasconcelos PFC, Travassos-da-Rosa JFS, editores. An overview of arbovirology in Brazil and neighbouring countries. Belém: Instituto Evandro Chagas; 1998. p. 72-99.

9. Alencar J, Rodriguez-Fernández J, Dégallier N, Marcondes CB, Costa JM, Guimarães AE. Multivariate discrimination between two cryptic Haemagogus species associated with the transmission of yellow fever virus in the Americas. J Am Mosq Control Assoc 2009; 25:18-24.

10. Medeiros AS, Marcondes CB, Azevedo PRM, Jerônimo SMB, Macedo e Silva VP, Ximenes MFFM. Seasonal variation of potential flavivirus vectors in an urban biological reserve in Northeastern Brazil. J Med Entomol 2009; 46:1450-1457.

11. Kumm H, Cerqueira NL. The Haemagogus mosquitoes of Brazil. Bull Entomol Res 1951; 42:169-181.

12. LabartheN, Serrão ML,Melo YF, Oliveira SJ,Lourenço-de-Oliveira R. Potentialvectors of Dirofilaria immitis (Leidy, 1856) in Itacoatiara oceanic region of Niterói Municipality State of Rio de Janeiro Brazil. Mem Inst Oswaldo Cruz 1998; 93:425-432.

13. Mitchell CJ, Forattini OP, Miller BR. Vector competence experiments with Rocio virus and three mosquito species from the epidemic zone in Brazil. Rev Saude Publica 1986; 20:171-177.

14. Soper FL, Penna H, Cardoso E, Serafim Jr J, Frobisher Jr M, Pinheiro J. Yellow fever without Aedes aegypti. Study of a rural epidemic in the Valle do Chanaan, Espirito Santo, Brazil, 1932. Am J Hyg 1933; 18:555-587.

15. Vasconcelos PF, Costa ZG, Travassos-da-Rosa ES, Luna E, Rodrigues SG Barros VL, et al. Epidemic of jungle yellow fever in Brazil: implications of climatic alterations in disease spread. J Med Virol 2001; 65:598-604. 